\title{
Formulation and In-Vitro Evaluation of Raft Forming Chewable Tablets of Ranitidine Hydrochloride
}

\author{
Hemali Soni ${ }^{1}$, Dr. V. A. Patel ${ }^{2}$ \\ ${ }^{1}$ Department of Pharmaceutics, A.R. College of Pharmacy, Gujarat Technological University, Gujarat, India \\ ${ }^{2}$ Associate Professor, Department of Pharmaceutics, A.R. College of Pharmacy, Gujarat Technological University, Gujarat, India
}

\begin{abstract}
The present study was aimed to formulate and develop raft forming chewable tablets of ranitidine hydrochloride for effective treatment of Gastro Esophageal Reflux Disease. Raft forming chewable tablet was developed using pectin as a raft forming polymer. Optimization of the formulation was done using $3^{2}$ full factorial design. The tablets were evaluated for various physicochemical parameters and in vitro drug release study. Tablets have shown satisfactory results when evaluated for hardness, friability, weight variation, drug content, raft strength and acid neutralizing capacity. Out of all factorial batches i.e. F1 to F9, F6 has shown promising results of raft strength as it is sufficient for the prevention of the reflux in the esophagus.
\end{abstract}

Keywords: Ranitidine Hydrochloride, Raft forming chewable tablets, Pectin as a raft forming agent, Acid Neutralizing Capacity

\section{Introduction}

By novel drug delivery system, continuous delivery of the drug at a predictable kinetic over an extended period of time can be achieved. The advantage of this system includes reduction in the drug related side effects which is due to controlled therapeutic blood level instead of oscillating blood level. Another advantage is improved patient compliance because of reduced dosing frequency and reduction of total dose of the drug which is to be administered [1].

\subsection{Gastro retentive drug delivery system (GRDDS):}

Gastro retentive drug delivery system is a site specific delivery system. It delivers the drug either in stomach or in intestine. The drug delivery is obtained by retention of dosage form in stomach and the drug is released in a controlled manner to the specific site either in stomach, duodenum or in intestine [2].

\subsection{Raft forming system [2],[3],[4],[5]}

This system focus more for delivery of antacid and delivery of drugs used to treat gastrointestinal infection and disorders. The basic mechanism involves formation of viscous cohesive gel when the system comes in contact with gastric fluid. In this each portion of liquid swells and forms a continuous layer of gel known as raft. The raft floats because of buoyancy created by formation of $\mathrm{CO}_{2}$. This raft acts as a physical barrier to prevent the reflex of gastric content into the esophagus. This raft forming system contains a gel forming agent and alkaline bicarbonates or carbonates which is responsible for making the system less dense than the gastric fluid and to float on the gastric fluid.

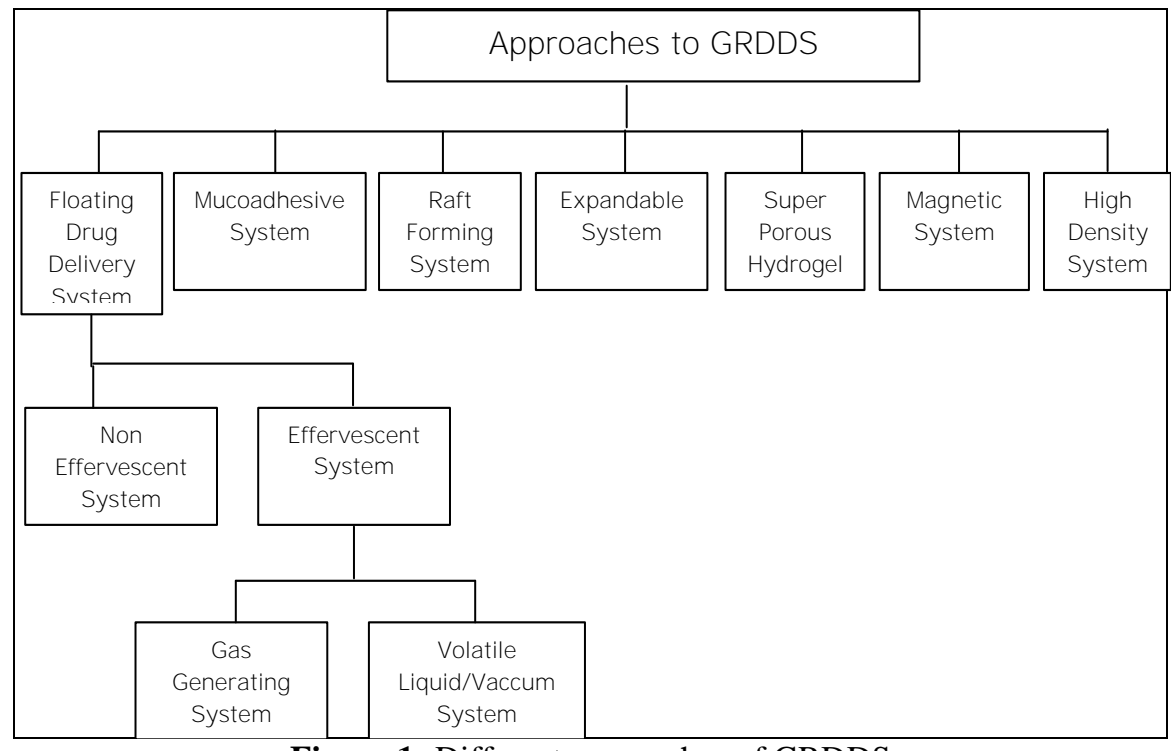

Figure 1: Different approaches of GRDDS 


\section{International Journal of Science and Research (IJSR) \\ ISSN (Online): 2319-7064 \\ Index Copernicus Value (2013): 6.14 | Impact Factor (2015): 6.391}

1.3 Effect of sodium bicarbonate on the drug release from raft forming system:

Sodium bicarbonate is used as a gas generating agent. Gas generating agent sodium bicarbonate interacts with the gastric acid and generates carbon dioxide which gets entrapped within the swellable matrix. Carbonate or bicarbonate may be present in the amount ranges from $5 \%$ to $50 \%$ and preferably from about $10 \%$ to $30 \%$ by weight of composition. Increasing the concentration of bicarbonate decreases the floating lag time because of faster and higher carbon dioxide generation. At higher concentration of effervescent agent, coating of the tablet becomes less stable. This is because of increase in the internal pressure and there by rupturing the polymer coating which ultimately results in sudden increase in drug release.

\subsection{Advantages of raft forming system:}

- It is used for the treatment of heartburn and oesophagitis. It is also useful to treat laryngopharyngeal reflux (LPR) and gastro esophageal reflux disease.

- It does not interfere with activity of anti secretory agent e.g. cimetidine.

- Rapid and long duration of action can be achieved. It shows its action within seconds.

- It may not interfere with the function of pyloric sphincter.

- Improved patient compliance.

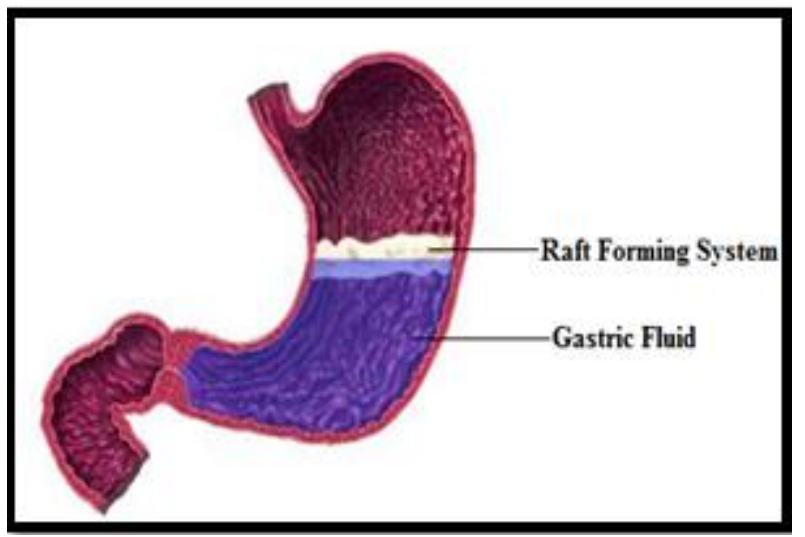

Figure 2: Raft formation in stomach

\section{Materials and Method}

\subsection{Materials}

Ranitidine Hydrochloride, Pectin, Sodium Bicarbonate, Calcium Carbonate, Mannitol, PVP K30, Isopropyl Alcohol, Aspartame, Magnesium Stearate,Talc.

\subsection{Method}

Drug, polymer and other ingredients were weighed accurately. All ingredients except the binder and lubricant were mixed thoroughly. PVP K30 was dissolved in sufficient quantity of isopropyl alcohol and added to a powder mixture to prepare dough wet mass. The prepared wet mass was passed through a 22\# sieve. The granules were allowed to dry in a hot air oven and then resifted through a 40\# sieve. The granules were collected and lubricated. Tablets were compressed by a $12.7 \mathrm{~mm}$ diameter flat punch with the help of a rotary tablet compression machine.

Table 1: Formulations of preliminary batches (PB1-PB5)

\begin{tabular}{|c|c|c|c|c|c|}
\hline Ingredients & $\begin{array}{c}\text { PB1 } \\
\text { (mg) }\end{array}$ & $\begin{array}{c}\text { PB2 } \\
\text { (mg) }\end{array}$ & $\begin{array}{c}\text { PB3 } \\
\text { (mg) }\end{array}$ & $\begin{array}{c}\text { PB4 } \\
\text { (mg) }\end{array}$ & $\begin{array}{c}\text { PB5 } \\
\text { (mg) }\end{array}$ \\
\hline Ranitidine Hydrochloride & 168 & 168 & 168 & 168 & 168 \\
\hline Pectin & 300 & 300 & 350 & 350 & 400 \\
\hline Sodium Bicarbonate & 25 & 25 & 25 & 25 & 25 \\
\hline Calcium Carbonate & 150 & 232 & 180 & 232 & 180 \\
\hline D-Mannitol & 282 & 200 & 202 & 150 & 152 \\
\hline Pvp K30 & 30 & 30 & 30 & 30 & 30 \\
\hline Aspartame & 25 & 25 & 25 & 25 & 25 \\
\hline Magnesium Stearate & 10 & 10 & 10 & 10 & 10 \\
\hline Talc & 10 & 10 & 10 & 10 & 10 \\
\hline
\end{tabular}

Table 2: Formulations of preliminary batches of (PB6-

\begin{tabular}{|c|c|c|c|c|c|}
\hline \multicolumn{1}{c}{ PB10) } \\
\hline Ingredients & $\begin{array}{c}\text { PB6 } \\
(\mathrm{mg})\end{array}$ & $\begin{array}{c}\text { PB7 } \\
(\mathrm{mg})\end{array}$ & $\begin{array}{c}\text { PB8 } \\
(\mathrm{mg})\end{array}$ & $\begin{array}{c}\text { PB9 } \\
(\mathrm{mg})\end{array}$ & $\begin{array}{c}\text { PB10 } \\
(\mathrm{mg})\end{array}$ \\
\hline Ranitidine Hydrochloride & 168 & 168 & 168 & 168 & 168 \\
\hline Pectin & 400 & 450 & 450 & 450 & 450 \\
\hline Sodium Bicarbonate & 25 & 25 & 50 & 25 & 57 \\
\hline Calcium Carbonate & 232 & 182 & 232 & 232 & 200 \\
\hline D-Mannitol & 100 & 100 & 25 & 50 & 50 \\
\hline Pvp K30 & 30 & 30 & 30 & 30 & 30 \\
\hline Aspartame & 25 & 25 & 25 & 25 & 25 \\
\hline Magnesium Stearate & 10 & 10 & 10 & 10 & 10 \\
\hline Talc & 10 & 10 & 10 & 10 & 10 \\
\hline
\end{tabular}

Optimization by $\mathbf{3}^{2}$ full factorial design:

- Two factors three level $\left(3^{2}\right)$ full factorial design was employed for development of Ranitidine Hydrochloride raft forming chewable tablets.

- Amount of pectin and amount of calcium carbonate were selected as independent variables

- Raft strength, Acid Neutralizing Capacity and \%drug release were selected as dependent variables.

Independent variables were as follow:

$\mathrm{X} 1=$ Amount of pectin

$\mathrm{X} 2=$ Amount of calcium carbonate

\section{Dependent variables were as follow:}

Y1= Raft strength

Y2= Acid Neutralizing Capacity

$\mathrm{Y} 3=\%$ drug release

Table 3: Coding of actual values for factorial design

\begin{tabular}{|c|c|c|c|}
\hline \multicolumn{3}{|c|}{ Transformation of coded values in actual values } \\
\hline \multirow{2}{*}{$\begin{array}{c}\text { Independent } \\
\text { Variables }\end{array}$} & \multicolumn{3}{|c|}{ Levels } \\
\cline { 2 - 4 } & $\begin{array}{c}\text { Low } \\
(-1)\end{array}$ & $\begin{array}{c}\text { Medium } \\
(0)\end{array}$ & $\begin{array}{c}\text { High } \\
(+1)\end{array}$ \\
\hline Amount of pectin $\left(\mathrm{X}_{1}\right)(\mathrm{mg})$ & 425 & 450 & 475 \\
\hline Amount of calcium carbonate $\left(\mathrm{X}_{2}\right)(\mathrm{mg})$ & 200 & 225 & 250 \\
\hline
\end{tabular}




\section{International Journal of Science and Research (IJSR) \\ ISSN (Online): 2319-7064}

Index Copernicus Value (2013): 6.14 | Impact Factor (2015): 6.391

Table 4: Factor combination as per $3^{2}$ full factorial design

\begin{tabular}{|c|c|c|}
\hline \multirow{2}{*}{ Formulation } & \multicolumn{2}{|c|}{ Coded factor level } \\
\cline { 2 - 3 } & $\mathrm{X}_{1}$ & $\mathrm{X}_{2}$ \\
\hline F1 & -1 & -1 \\
\hline F2 & -1 & 0 \\
\hline F3 & -1 & +1 \\
\hline F4 & 0 & -1 \\
\hline F5 & 0 & 0 \\
\hline F6 & 0 & +1 \\
\hline F7 & +1 & -1 \\
\hline F8 & +1 & 0 \\
\hline F9 & +1 & +1 \\
\hline \multicolumn{2}{|r|}{}
\end{tabular}

\section{Evaluation Parameters}

\subsection{Pre-Compression Evaluation Parameters:}

Angle of repose $(\theta)$, bulk density (gm/ml), tapped density $(\mathrm{gm} / \mathrm{ml})$, carr's index (\%) and hausner's ratio were evaluated to determine the flow property of the prepared granule's mixture.

\subsection{Post-Compression Evaluation Parameters}

\section{Weight Variation Test [6]:}

- Twenty tablets were randomly selected, weighed individually and the average weight was calculated. Not more than two of the individual weights deviate from the average weight by 5\% as per IP 2010.

Table 5: IP standards for weight variation test

\begin{tabular}{|c|c|}
\hline Average weight of tablets & \% deviation \\
\hline $80 \mathrm{mg}$ or less & 10 \\
\hline More than $80 \mathrm{mg}$ but less than $250 \mathrm{mg}$ & 7.5 \\
\hline $250 \mathrm{mg}$ or more & 5 \\
\hline
\end{tabular}

\section{Friability [6]:}

- $\quad$ Friability was determined by using roche friabilator. Six tablets were weighed and placed in the friabilator. This friabilator was then operated at $25 \mathrm{rpm}$ for four minutes. The tablets were then de-dusted and weighed. It should not be more than $1 \%$. \%Friability was calculated as per the following equation:

$$
\% \text { friability }=\frac{\text { Initial Weight }- \text { Final Weight }}{\text { InitialWeight }} \times 100
$$

\section{Hardness [6]:}

- The Monsanto hardness tester was used to determine the tablet hardness. Scale was adjusted to zero and load was gradually increased until the tablet fractured. The value of the load at that point gave the measure of the hardness of tablet. Hardness was expressed in $\mathrm{kg} / \mathrm{cm}^{2}$.

\section{Drug Content [6]:}

- Twenty tablets were weighted and powdered in a mortar. Accurately weighted quantity of the powder equivalent to about $168 \mathrm{mg}$ of Ranitidine Hydrochloride was diluted to $100 \mathrm{ml}$ with $0.1 \mathrm{~N} \mathrm{HCl}$ in $100 \mathrm{ml}$ volumetric flask. It was stirred for 15 minutes and filtered. $1 \mathrm{ml}$ of the filtrate was diluted with $0.1 \mathrm{~N} \mathrm{HCl}$ to produce $100 \mathrm{mcg} / \mathrm{ml}$ solution. The absorbance of the resulting solution was measured at $\lambda \max 312.5 \mathrm{~nm}$ and the content of Ranitidine Hydrochloride was calculated from the absorbance obtained.

\section{Raft Strength Measurement [7]:}

- A tablet powder equivalent to unit dose was transferred to $150 \mathrm{ml}$ of $0.1 \mathrm{~N} \mathrm{HCl}$ and maintained at $37^{\circ} \mathrm{C}$ in a 250 $\mathrm{ml}$ glass beaker. Each raft was allowed to form around an L-shaped wire probe (diameter: $1.2 \mathrm{~mm}$ ) held upright in the beaker throughout the whole period (30 $\mathrm{min})$ of raft development. Raft strength was estimated using the modified balance method. Water was added drop wise to the pan and the weight of water required to break the raft was recorded.

Note: A double-pan dispensing balance was modified for raft strength measurement. One pan of the dispensing balance was replaced with an L-shaped wire probe as shown in Figure.

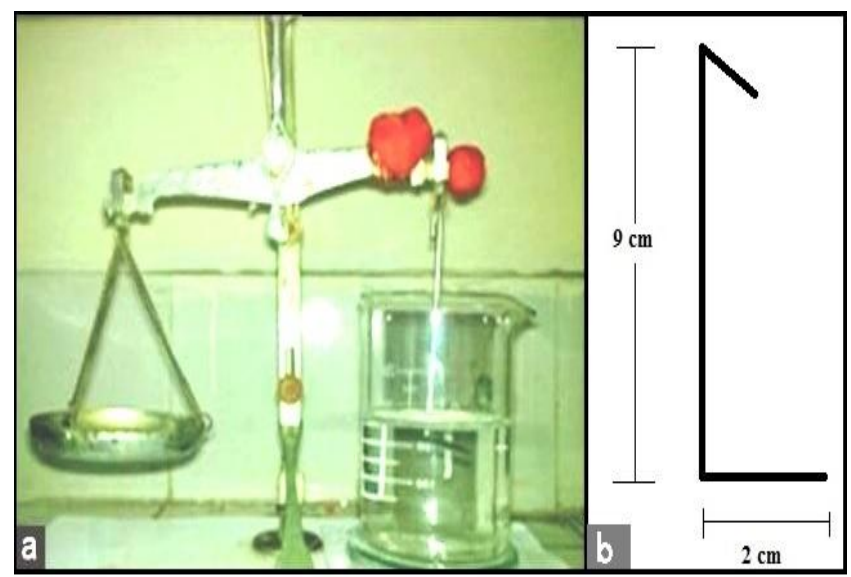

(a) Modified balance method (b) Wire probe for raft strength measurement

Figure 3: Modified dispensing balance for raft strength measurement

Acid Neutralizing Capacity [8]:

- A tablet powder equivalent to unit dose was taken in a 250-ml beaker. Water was added to make a total volume of about $70 \mathrm{ml}$, heated to $37^{\circ} \mathrm{C}$ and stirred continuously by maintaining the temperature at $37^{\circ} \mathrm{C} .30 \mathrm{ml}$ of $1 \mathrm{M}$ hydrochloric acid (previously heated to $37^{\circ} \mathrm{C}$ ) was added and mixture was maintained at $37^{\circ} \mathrm{C}$ for 15 minutes with continuous stirring. The excess acid was titrated with $1 \mathrm{M}$ sodium hydroxide to a $\mathrm{pH}$ of 3.5 . The number of $\mathrm{mEq}$ of acid consumed by the tablet tested was calculated by the following formula:

$$
\text { Total } m E q=\left(30 \times M_{H C l}\right)-\left(V_{\mathrm{NaOH}} \times M_{N a O H}\right)
$$

Where,

$\mathrm{M}_{\mathrm{HCl}}=$ molarity of hydrochloric acid

$\mathrm{M}_{\mathrm{NaOH}}=$ molarity of sodium hydroxide

$\mathrm{V}_{\mathrm{NaOH}}=$ volume of sodium hydroxide

\section{In Vitro Drug Release Study [7]:}

- In vitro drug release study of Ranitidine Hydrochloride chewable tablets $(\mathrm{n}=3)$ was performed using USP apparatus II fitted with a paddle (50 r.p.m.) at 


\section{International Journal of Science and Research (IJSR) \\ ISSN (Online): 2319-7064 \\ Index Copernicus Value (2013): 6.14 | Impact Factor (2015): 6.391}

$37 \pm 0.5^{\circ} \mathrm{C}$ using a simulated gastric fluid $(\mathrm{pH} 1.2 ; 900$ $\mathrm{ml}$ ) as a dissolution medium. Unit dose was powdered and then added to the dissolution medium. At predetermined time intervals, $10-\mathrm{ml}$ samples were withdrawn, filtered through a $0.45-\mu \mathrm{m}$ membrane filter and analyzed at $312.5 \mathrm{~nm}$ using a UV spectrophotometer. Cumulative percentage drug release was calculated using an equation obtained from a calibration curve.

\section{Result and Discussion}

\subsection{Results of Preliminary Batches}

Table 6: Pre-compression data of Preliminary batches

\begin{tabular}{|c|c|c|c|c|c|}
\hline Batch no. & $\begin{array}{c}\text { Angle of } \\
\text { repose }\end{array}$ & $\begin{array}{c}\text { Bulk } \\
\text { density }\end{array}$ & $\begin{array}{c}\text { Tapped } \\
\text { density }\end{array}$ & $\begin{array}{c}\text { Carr's } \\
\text { index }\end{array}$ & $\begin{array}{c}\text { Hausner's } \\
\text { ratio }\end{array}$ \\
\hline PB1 & 34.97 & 0.34 & 0.40 & 12.5 & 1.14 \\
\hline PB2 & 33.83 & 0.35 & 0.39 & 12.8 & 1.14 \\
\hline PB3 & 33.8 & 0.39 & 0.46 & 15.2 & 1.17 \\
\hline PB4 & 32.26 & 0.375 & 0.46 & 18.4 & 1.22 \\
\hline PB5 & 32.69 & 0.33 & 0.392 & 15.8 & 1.19 \\
\hline PB6 & 33.16 & 0.35 & 0.43 & 18.6 & 1.23 \\
\hline PB7 & 32.93 & 0.33 & 0.39 & 15.3 & 1.18 \\
\hline PB8 & 35.94 & 0.36 & 0.45 & 20 & 1.25 \\
\hline PB9 & 34.92 & 0.378 & 0.46 & 17.82 & 1.22 \\
\hline PB10 & 33.41 & 0.342 & 0.417 & 17.8 & 1.21 \\
\hline
\end{tabular}

The prepared granules for raft forming chewable tablets were characterized for angle of repose, bulk density, tapped density, carr's index and hausner's ratio which are shown in table. Angle of repose of all batches was within $31^{\circ}-35^{\circ}$, carr's index of all batches was within $11-20$ and hausner's ratio of all batches was found within $1.12-1.25$ which indicate good flow property of granules.

Table 7: Post - compression data of Preliminary batches

\begin{tabular}{|c|c|c|c|}
\hline Batch no. & $\begin{array}{c}\text { Tablet weight } \\
(\mathrm{mg})^{*}\end{array}$ & Diameter $(\mathrm{mm})^{* *}$ & Thickness $(\mathrm{mm})^{* *}$ \\
\hline PB1 & $998.5 \pm 3.7$ & $11.96 \pm 0.05$ & $4.92 \pm 0.04$ \\
\hline PB2 & $998.5 \pm 4.8$ & $11.94 \pm 0.05$ & $4.96 \pm 0.05$ \\
\hline PB3 & $998.0 \pm 4.1$ & $11.98 \pm 0.04$ & $4.98 \pm 0.04$ \\
\hline PB4 & $998.5 \pm 4.8$ & $11.94 \pm 0.05$ & $4.92 \pm 0.04$ \\
\hline PB5 & $998.5 \pm 3.7$ & $11.94 \pm 0.05$ & $4.94 \pm 0.05$ \\
\hline PB6 & $997.0 \pm 6.6$ & $11.96 \pm 0.05$ & $4.96 \pm 0.05$ \\
\hline PB7 & $996.0 \pm 7.5$ & $11.94 \pm 0.08$ & $4.94 \pm 0.05$ \\
\hline PB8 & $997.0 \pm 6.5$ & $11.96 \pm 0.1$ & $4.92 \pm 0.1$ \\
\hline PB9 & $997.0 \pm 5.5$ & $11.98 \pm 0.04$ & $4.99 \pm 0.07$ \\
\hline PB10 & $998.5 \pm 3.7$ & $11.96 \pm 0.05$ & $4.98 \pm 0.04$ \\
\hline
\end{tabular}

*Mean \pm SD $(\mathrm{n}=20) * *(\mathrm{n}=6)$

- All prepared batches were subjected for weight variation study and results are given in table. The deviation from the average weight was found to be within the prescribed official limits and pass the test.

Table 8: Post - compression data of Preliminary batches

\begin{tabular}{|c|c|c|}
\hline Batch no. & Friability (\%) $* *$ & Hardness $\left(\mathrm{kg} / \mathrm{cm}^{2}\right)^{* *}$ \\
\hline PB1 & $0.6 \pm 0.01$ & $4.4 \pm 0.55$ \\
\hline PB2 & $0.58 \pm 0.01$ & $4.8 \pm 0.45$ \\
\hline PB3 & $0.6 \pm 0.01$ & $5.4 \pm 0.54$ \\
\hline PB4 & $0.6 \pm 0.01$ & $5.0 \pm 0.71$ \\
\hline PB5 & $0.65 \pm 0.01$ & $4.6 \pm 0.54$ \\
\hline PB6 & $0.75 \pm 0.02$ & $4.2 \pm 0.44$ \\
\hline PB7 & $0.59 \pm 0.01$ & $4.4 \pm 0.45$ \\
\hline PB8 & $0.79 \pm 0.02$ & $4.4 \pm 0.55$ \\
\hline PB9 & $0.65 \pm 0.01$ & $5.6 \pm 0.55$ \\
\hline PB10 & $0.68 \pm 0.02$ & $5.0 \pm 0.71$ \\
\hline
\end{tabular}

$* *$ Mean \pm SD $(\mathrm{n}=6)$

- Hardness of tablets was found to be in the range of $4-5$ $\mathrm{kg} / \mathrm{cm}^{2}$ which is sufficient for chewable tablet. The friability of all tablets was found to be in range of $0.58 \%$ - $0.79 \%$ which is less than $1 \%$ that showed good mechanical strength.

Table 9: Data for raft strength and Acid Neutralizing Capacity of preliminary batches

\begin{tabular}{|c|c|c|}
\hline Batch no. & Raft strength (gm)* & $\begin{array}{c}\text { Acid Neutralizing Capacity } \\
(\mathrm{mEq}) *\end{array}$ \\
\hline PB1 & $0.96 \pm 0.01$ & $6.2 \pm 0.1$ \\
\hline PB2 & $1.13 \pm 0.01$ & $6.2 \pm 0.1$ \\
\hline PB3 & $2.12 \pm 0.02$ & $6.4 \pm 0.2$ \\
\hline PB4 & $2.3 \pm 0.02$ & $6.5 \pm 0.1$ \\
\hline PB5 & $2.65 \pm 0.01$ & $6.5 \pm 0.1$ \\
\hline PB6 & $2.8 \pm 0.1$ & $6.8 \pm 0.1$ \\
\hline PB7 & $3.02 \pm 0.1$ & $6.5 \pm 0.2$ \\
\hline PB8 & $3.2 \pm 0.05$ & $6.9 \pm 0.2$ \\
\hline PB9 & $3.5 \pm 0.1$ & $7.0 \pm 0.1$ \\
\hline PB10 & $3.52 \pm 0.05$ & $7.2 \pm 0.3$ \\
\hline
\end{tabular}

- All batches had good raft strength which was within the range of $0.96-3.52 \mathrm{~g}$ and all batches had Acid Neutralizing Capacity within the range of $6.2-7.2 \mathrm{mEq}$. Raft strength was found to be sufficient for prevention of reflux of gastric content into the esophagus.

${ }^{*}$ mean $\pm \mathrm{SD}(\mathrm{n}=3)$

Table 10: Dissolution profile of preliminary batches (PB1 - PB5)

\begin{tabular}{|c|c|c|c|c|c|}
\hline \multirow{2}{*}{$\begin{array}{c}\text { Time } \\
(\mathrm{min})\end{array}$} & \multicolumn{5}{|c|}{ Cumulative percentage drug release* } \\
\cline { 2 - 6 } & PB1 & PB2 & PB3 & PB4 & PB5 \\
\hline 0 & 0 & 0 & 0 & 0 & 0 \\
\hline 10 & $60.2 \pm 0.5$ & $59.85 \pm 0.2$ & $62.82 \pm 1.05$ & $61.5 \pm 0.4$ & $63.89 \pm 0.5$ \\
\hline 20 & $70.26 \pm 0.2$ & $70.85 \pm 0.5$ & $72.53 \pm 0.1$ & $71.96 \pm 0.1$ & $73.41 \pm 0.7$ \\
\hline 30 & $85.62 \pm 1.02$ & $84.52 \pm 1.1$ & $86.52 \pm 0.4$ & $87.42 \pm 0.1$ & $85.25 \pm 0.4$ \\
\hline 40 & $90.52 \pm 0.8$ & $89.89 \pm 0.9$ & $91.25 \pm 0.7$ & $93.12 \pm 0.2$ & $91.52 \pm 0.2$ \\
\hline 50 & $94.35 \pm 0.6$ & $96.81 \pm 0.4$ & $95.72 \pm 0.2$ & $96.24 \pm 0.5$ & $97.87 \pm 0.5$ \\
\hline 60 & $96.2 \pm 1.01$ & $97.3 \pm 0.6$ & $97.84 \pm 0.2$ & $98.2 \pm 0.2$ & $99.52 \pm 0.9$ \\
\hline \multicolumn{5}{|c|}{}
\end{tabular}


International Journal of Science and Research (IJSR)
ISSN (Online): 2319-7064
Index Copernicus Value (2013): 6.14 | Impact Factor (2015): 6.391

Table 11: Dissolution profile of preliminary batches (PB6 - PB10)

\begin{tabular}{|c|c|c|c|c|c|}
\hline \multirow{2}{*}{ Time (min) } & \multicolumn{5}{|c|}{ Cumulative percentage drug release* } \\
\cline { 2 - 6 } & PB6 & PB7 & PB8 & PB9 & PB10 \\
\hline 0 & 0 & 0 & 0 & 0 & 0 \\
\hline 10 & $62.66 \pm 0.2$ & $64.25 \pm 0.12$ & $71.57 \pm 0.1$ & $68.25 \pm 0.6$ & $69.25 \pm 0.3$ \\
\hline 20 & $63.25 \pm 0.5$ & $74.56 \pm 0.5$ & $77.83 \pm 0.2$ & $76.52 \pm 0.2$ & $75.25 \pm 1.1$ \\
\hline 30 & $90.17 \pm 0.6$ & $86.25 \pm 0.4$ & $97.28 \pm 0.5$ & $87.54 \pm 1.2$ & $90.25 \pm 0.5$ \\
\hline 40 & $90.34 \pm 1.2$ & $94.23 \pm 1.1$ & $98.4 \pm 0.9$ & $95.26 \pm 1.05$ & $96.20 \pm 0.2$ \\
\hline 50 & $99.08 \pm 1.02$ & $96.52 \pm 1.01$ & $99.51 \pm 1.04$ & $97.48 \pm 0.8$ & $98.62 \pm 0.5$ \\
\hline 60 & $100.05 \pm 1.00$ & $98.23 \pm 0.9$ & $100.12 \pm 0.5$ & $98.5 \pm 0.8$ & $99.98 \pm 0.6$ \\
\hline
\end{tabular}

$*$ mean \pm SD $(n=3)$

- From the data, it was concluded that, formulation with maximum amount of pectin and calcium carbonate

\subsection{Results of Factorial Batches} showed higher release of drug amonst all the batches.

Table 12: Pre - compression data of factorial batches

\begin{tabular}{|c|c|c|c|c|c|}
\hline $\begin{array}{c}\text { Batch } \\
\text { no. }\end{array}$ & $\begin{array}{c}\text { Angle of } \\
\text { repose }\end{array}$ & $\begin{array}{c}\text { Bulk } \\
\text { density }\end{array}$ & $\begin{array}{c}\text { Tapped } \\
\text { density }\end{array}$ & Carr's index & Hausner's ratio \\
\hline F1 & $33.87 \pm 0.52$ & $0.61 \pm 0.05$ & $0.69 \pm 0.01$ & $10.94 \pm 0.2$ & $1.12 \pm 0.01$ \\
\hline F2 & $35.14 \pm 0.55$ & $0.60 \pm 0.01$ & $0.68 \pm 0.05$ & $11.76 \pm 0.1$ & $1.13 \pm 0.02$ \\
\hline F3 & $34.17 \pm 0.17$ & $0.58 \pm 0.05$ & $0.69 \pm 0.03$ & $15.94 \pm 0.5$ & $1.18 \pm 0.01$ \\
\hline F4 & $34.12 \pm 0.62$ & $0.50 \pm 0.03$ & $0.62 \pm 0.01$ & $19.35 \pm 0.3$ & $1.24 \pm 0.05$ \\
\hline F5 & $33.77 \pm 1.67$ & $0.59 \pm 0.01$ & $0.72 \pm 0.05$ & $18.05 \pm 0.2$ & $1.22 \pm 0.01$ \\
\hline F6 & $32.48 \pm 0.32$ & $0.59 \pm 0.09$ & $0.69 \pm 0.03$ & $14.49 \pm 0.8$ & $1.16 \pm 0.03$ \\
\hline F7 & $33.39 \pm 0.34$ & $0.59 \pm 0.06$ & $0.65 \pm 0.08$ & $9.23 \pm 0.6$ & $1.10 \pm 0.01$ \\
\hline F8 & $32.56 \pm 1.05$ & $0.59 \pm 0.02$ & $0.72 \pm 0.1$ & $18.05 \pm 0.3$ & $1.22 \pm 0.02$ \\
\hline F9 & $34.26 \pm 0.89$ & $0.80 \pm 0.02$ & $0.94 \pm 0.06$ & $14.8 \pm 0.4$ & $1.17 \pm 0.03$ \\
\hline
\end{tabular}

$*$ Mean \pm SD $(\mathrm{n}=3)$

The prepared granules for raft forming chewable tablets were characterized for angle of repose, bulk density, tapped density, carr's index and hausner's ratio which are shown in table, which indicate good flow property of granules.

Table 13: Post - compression data of factorial batches

\begin{tabular}{|c|c|c|c|}
\hline Batch no. & $\begin{array}{c}\text { Tablet weight } \\
(\mathrm{mg})^{*}\end{array}$ & $\begin{array}{c}\text { Diameter } \\
(\mathrm{mm})^{* *}\end{array}$ & $\begin{array}{c}\text { Thickness } \\
(\mathrm{mm})^{* *}\end{array}$ \\
\hline F1 & $1000.3 \pm 2.2$ & $12.69 \pm 0.04$ & $5.63 \pm 0.010$ \\
\hline F2 & $1006.7 \pm 2.5$ & $12.70 \pm 0.05$ & $5.67 \pm 0.012$ \\
\hline F3 & $999.7 \pm 5.6$ & $12.70 \pm 0.06$ & $5.62 \pm 0.020$ \\
\hline F4 & $1000.6 \pm 1.5$ & $12.71 \pm 0.01$ & $5.63 \pm 0.011$ \\
\hline F5 & $999.5 \pm 0.6$ & $12.70 \pm 0.02$ & $5.63 \pm 0.020$ \\
\hline F6 & $1000.2 \pm 3.7$ & $12.69 \pm 0.01$ & $5.62 \pm 0.015$ \\
\hline F7 & $999.8 \pm 4.8$ & $12.68 \pm 0.03$ & $5.68 \pm 0.015$ \\
\hline F8 & $999.3 \pm 3.6$ & $12.71 \pm 0.05$ & $5.66 \pm 0.011$ \\
\hline F9 & $1000.5 \pm 5.8$ & $12.70 \pm 0.04$ & $5.64 \pm 0.020$ \\
\hline
\end{tabular}

** mean \pm SD $(\mathrm{n}=6), *(\mathrm{n}=2)$

- All prepared batches were subjected for weight variation study and results are given in table. The deviation from the average weight was found to be within the prescribed official limits and pass the test.

Table 14: Post - compression data of factorial batches

\begin{tabular}{|c|c|c|c|}
\hline $\begin{array}{c}\text { Batch } \\
\text { no. }\end{array}$ & $\begin{array}{c}\text { Friability } \\
(\%) * *\end{array}$ & $\begin{array}{c}\text { Hardness } \\
\left(\mathrm{kg} / \mathrm{cm}^{2}\right)\end{array} * *$ & Drug content $*$ \\
\hline F1 & $0.98 \pm 0.01$ & $4.4 \pm 0.54$ & $97.275 \pm 0.14$ \\
\hline F2 & $0.65 \pm 0.01$ & $4.6 \pm 0.57$ & $99.995 \pm 0.28$ \\
\hline F3 & $0.33 \pm 0.02$ & $4.2 \pm 0.45$ & $100.805 \pm 0.57$ \\
\hline F4 & $0.82 \pm 0.1$ & $4.2 \pm 0.42$ & $98.385 \pm 0.28$ \\
\hline F5 & $0.66 \pm 0.01$ & $4.6 \pm 0.49$ & $100.91 \pm 0.14$ \\
\hline F6 & $0.49 \pm 0.03$ & $4.2 \pm 0.52$ & $102.12 \pm 0.14$ \\
\hline
\end{tabular}

\begin{tabular}{|c|c|c|c|}
\hline F7 & $0.33 \pm 0.1$ & $4.6 \pm 0.57$ & $99.695 \pm 0.13$ \\
\hline F8 & $0.65 \pm 0.01$ & $4.4 \pm 0.54$ & $103.02 \pm 0.28$ \\
\hline F9 & $0.32 \pm 0.02$ & $4.6 \pm 0.57$ & $102.115 \pm 0.43$ \\
\hline
\end{tabular}

**mean \pm SD $(\mathrm{n}=6),{ }^{*}(\mathrm{n}=2)$

- Hardness of tablets was found to be in the range of 4-5 $\mathrm{kg} / \mathrm{cm}^{2}$ which is sufficient for chewable tablet. The friability of all tablets was found to be in range of $0.32 \%$ - $0.98 \%$ which is less than $1 \%$ that showed good mechanical strength.

Table 15: Data for raft strength and Acid Neutralizing Capacity of preliminary batches

\begin{tabular}{|c|c|c|}
\hline Batch no. & Raft strength (gm)* & $\begin{array}{c}\text { Acid Neutralizing } \\
\text { Capacity (mEq)* }\end{array}$ \\
\hline F1 & $2.68 \pm 0.02$ & $6.8 \pm 0.1$ \\
\hline F2 & $2.82 \pm 0.01$ & $7.1 \pm 0.2$ \\
\hline F3 & $3.05 \pm 0.01$ & $7.6 \pm 0.1$ \\
\hline F4 & $3.20 \pm 0.09$ & $7.4 \pm 0.1$ \\
\hline F5 & $3.59 \pm 0.07$ & $7.9 \pm 0.3$ \\
\hline F6 & $3.75 \pm 0.02$ & $8.2 \pm 0.1$ \\
\hline F7 & $3.72 \pm 0.01$ & $7.5 \pm 0.2$ \\
\hline F8 & $3.70 \pm 0.01$ & $8.4 \pm 0.1$ \\
\hline F9 & $3.69 \pm 0.03$ & $8.6 \pm 0.3$ \\
\hline
\end{tabular}

$*$ mean \pm SD $(\mathrm{n}=3)$

- All factorial batches had good raft strength which was within the range of $2.68-3.75 \mathrm{~g}$ and all batches had Acid Neutralizing Capacity within the range of 6.8 $8.6 \mathrm{mEq}$. Raft strength was found to be sufficient for prevention of reflux of gastric content into the esophagus. 


\section{International Journal of Science and Research (IJSR) ISSN (Online): 2319-7064}

Index Copernicus Value (2013): 6.14 | Impact Factor (2015): 6.391

Table 16: Dissolution profile of factorial batches (F1-F5)

\begin{tabular}{|c|c|c|c|c|c|}
\hline \multirow{2}{*}{$\begin{array}{l}\text { Time } \\
(\mathrm{min})\end{array}$} & \multicolumn{5}{|c|}{ Cumulative percentage drug release* } \\
\hline & F1 & F2 & F3 & $\mathrm{F} 4$ & F5 \\
\hline 0 & 0 & 0 & 0 & 0 & 0 \\
\hline 10 & $59.12 \pm 0.50$ & $62.66 \pm 0.72$ & $1.41 \pm 0.42$ & $58.12 \pm 0.72$ & $5.03+1$ \\
\hline 20 & $70.12 \pm 1$. & $71.23 \pm 0.93$ & $74.52 \pm 0.98$ & $72.16 \pm 1.02$ & $71.81 \pm 0.76$ \\
\hline 30 & $85.18 \pm 1.03$ & $86.56 \pm 1.01$ & $89.41 \pm 1$ & $82.49 \pm 0.38$ & $84.24 \pm 1.03$ \\
\hline 40 & $89.4 \pm 0.85$ & $90.34 \pm 1.08$ & $90.8 \pm 0.69$ & $89.12 \pm 0.90$ & $89.39 \pm 1.16$ \\
\hline 50 & $92.32 \pm 1.12$ & $94.11 \pm 1.07$ & $95.41 \pm 1.07$ & $92.12 \pm 0.76$ & $94.43 \pm 0.65$ \\
\hline 60 & $96.52 \pm 1.00$ & $97.56 \pm 1.20$ & $98.56 \pm 0.25$ & $98.68 \pm 1.08$ & $99.43 \pm 0.89$ \\
\hline
\end{tabular}

$*$ mean $\pm \mathrm{SD}(\mathrm{n}=3)$

Table 17: Dissolution profile of factorial batches (F6-F9)

\begin{tabular}{|c|c|c|c|c|}
\hline \multirow{2}{*}{$\begin{array}{l}\text { Time } \\
\text { (min) }\end{array}$} & \multicolumn{4}{|c|}{ Cumulative percentage drug release* } \\
\hline & F6 & F7 & F8 & F9 \\
\hline 0 & 0 & 0 & 0 & 0 \\
\hline 10 & $62.12 \pm 0.95$ & $63.46 \pm 0.77$ & $61.18 \pm 0.91$ & $65.06 \pm 0.79$ \\
\hline 20 & $70.56 \pm 1.01$ & $74.16 \pm 0.59$ & $70.16 \pm 1.02$ & $79.62 \pm 1.04$ \\
\hline 30 & $85.12 \pm 1.15$ & $84.43 \pm 1.11$ & $85.15 \pm 1.12$ & $86.25 \pm 0.36$ \\
\hline 40 & $92.43 \pm 0.73$ & $90.12 \pm 1.04$ & $89.12 \pm 0.79$ & $91.52 \pm 1.02$ \\
\hline 50 & $98.16 \pm 0.97$ & $94.42 \pm 0.62$ & $97.16 \pm 1.02$ & $98.81 \pm 0.88$ \\
\hline 60 & $100.97 \pm 1.00$ & $98.89 \pm 0.84$ & $99.56 \pm 1.01$ & $99.98 \pm 0.89$ \\
\hline
\end{tabular}

\section{Conclusion}

The raft forming chewable tablets of Ranitidine Hydrochloride were successfully formulated by wet granulation method. Pectin was used as a raft forming polymer and calcium carbonate was used to strengthen the raft formed by pectin. The formulation was optimized using two factors, three levels full factorial design. The amount of pectin $\left(\mathrm{X}_{1}\right)$ and amount of calcium carbonate $\left(\mathrm{X}_{2}\right)$ showed significant effect on the dependent variables $Y_{1}, Y_{2}$ and $Y_{3}$ which was raft strength, Acid Neutralizing Capacity and \% drug release respectively. In conclusion, the present study demonstrates the successful preparation of stable raft forming chewable tablets of Ranitidine Hydrochloride.

From all the result of factorial batches F1 to F9, F6 shows promising result for the raft strength which is sufficient for prevention of reflux in the esophagus.

\section{Referneces}

[1] Kumar Vikas, Sharma Arvind, Sharma Ashish, Joshi Gourav, Dhillon Vipasha, "Recent Advances In NDDS (Novel Drug Delivery System) For Delivery Of AntiHypertensive Drugs", International Journal of Drug Development \& Research Jan-March 2010, Vol. 3, Issue 1, pp 252-259.

[2] Bhavsar Dhaval Niranjanbhai, Varde Neha Mahendrakumar, C. Sini Surendran, Shah Viral H, Upadhyay, "Advances In Grdds: Raft Forming System A Review", Journal of Drug Delivery \& Therapeutics; 2012, 2(5), 123-128.

[3] Binoy.B, Jayachandran Nair, "C.V Floating Drug Delivery System- A new Approach In Gastric RetentionA Review”, Journal Of Drug Delivery Research, Vol 1 , Issue 3, 2012, 18-31.
[4] Kunal. P. Nayak, Pratik Upadhyay, Jayant Deshpande Arohi R. Valera, Nirav P. Chauhan, "Gastroretentive Drug Delivery Systems and Recent Approaches: A Review", Journal of Pharmaceutical Research and Opinion 2: 1 (2012) 1 - 8.

[5] Chandel et al., "Floating drug delivery systems: A better approach", International Current Pharmaceutical Journal 2012, 1(5): 110-118.

[6] M. Ehsanul H. Chowdhury, M. S. I. Pathan, "Preparation and evaluation of floating matrix tablets of Ranitidine Hydrochloride", The Pharma Innovation, Vol. 1 No. 7, 2012, 43-50.

[7] Mitul Patel, Priya Tolia, Bhavin Bhimani, Dr. Upendra Patel, "Formulation And Evaluation Of Raft Forming Chewable Tablet Containing Pantoprazole Sodium", International Journal Of Pharmaceutical Research And Bio-Science, 2014; Volume 3(2): 580-597.

[8] Gopal S. Gandhi, Dharmendra R. Mundhada, Shyamala Bhaskaran, "Formulation and Evaluation of Orodispersible Antacid Tablet For Geriatric Patient", Journal Of Pharmaceutical Research And Opininion, June 2011, Volume 01,Issue 01,25 - 27. 